\title{
WHENCE CAME THE PIONEERS OF IOWA?
}

BY F. I. HERRIOTT,

Professor in Drake University.

[Concluded from April. $]^{1}$

There is a subtle attraction about exclusive explanations of political events or institutional developments that is wont to lure us into orroneous conclusions-conclusions that are too extensive or sweeping. It is untrue to say that the population of Iowa prior to 1850 was made up entirely of emigrants from any one section of the country. The pioneer population, no less than the present population, we shall find, was an infusion of people hailing from various regions. The representatives of the several race elements each and all played parts more or less important in the life of the State. But in the coalescence or collision of the peoples from the various sections in their new habitat some one race or group of immigrants predominated and determined the character of the government and the general drift of political opinion. In what follows $I$ am concerned to ascertain and to make clear what the dominant elements or streams were among the pioneers of Iowa.

We have seen that while there are many facts in the history of Iowa that tend strongly to substantiate the tradition that New Englanders first settled the State the absence of the distinctive local institutions of New England and in their stead political conditions, institutions and social habits of radically unlike types, suggest, if they do not enforce the conclusion that peoples from other regions dominated by different habits and ideals constituted the major portions of the streams of pioneer immigration prior to 1850 . Our question now is-Whither shall we proceed from New England to discover the ancestral seats of the pioneers whose habits, notions and traditions of government and society so power-

\footnotetext{
1 Erratum. President Shelton's address, referred to on p. 375, was made in 1902 instead of 189:2 as stated.
} 
fully affected the currents of politics and the development of forms of government in Iowa during the formative period of the State when its fundamental institutions were given their "set" and the civic and social traits of the people were so largely determined? Into the lands of the tall pines and the deep snows north of the Great Lakes and the St. Lawrence; or into the middle states; or into the vast regions south of Mason and Dixon's line and the Obio river?

The nativity of the pioneers of Iowa, those settling in the State prior to 1850 , unfortunately cannot be determined precisely by a resort to census enumerations. We are compelled to have recourse to inductive proofs gathered from sundry sources and to various deductive or general considerations governing the movements of population westward from the Atlantic seaboard from colonial times up to the outbreak of the civil war. Such evidence is circumstantial and often variable in character; nevertheless it affords us bases for definite conclusions.

The character of a state's immigration is determined, of course, by many and various conditions and factors. But in the last analysis the nature of the immigration and the rate of influx are determined by two sets of conditions and causes, both being in the long run, of equal force and importance. The first set is the character of the economic advantages which a state offers and the expense of travel thereto. The second complex of causes is the conditions, economic, political and social, in the countries or states whence the population may or does emigrate. In brief, we shall discover the character of Iowa's pioneer population in sundry fundamental facts or laws that control the conduct of peoples in their migrations. We must appreciate Iowa's geographical location, the chief features of her topography, her natural products having commercial value, the routes and modes of travel to her borders. We must likewise realize the character of the predominant industries in the regions whence the state may have received its immigration and the economic, 
political, and social consequences with respect to the redundant population in those regions. Space limits obviously prevent satisfactory treatment of all these antecedent conditions and factors, and I shall consider chiefly the first set of considerations mentioned.

Furs, metals, wooded streams and beautiful prairies, with highly fertile acres and favorable climate, have been Iowa's chief economic advantages throughout her history. Prior to 1830 furs and metals were the attractions that lured frontiersmen within the State's borders. The one mineral found, viz: lead, while of consequence was not a very important factor so far as concerned its inımediate effect upon pioneer immigration. Furs, on the other hand, was an important factor. Buffalo and deer thourished on our prairies and beaver and otter thrived in our rivers and streams. Since 1840, however, neither our metals nor our fur bearing animals have constituted the predominant or persistent attractions of Iowa. The attraction has been her beautiful and bountiful lands.

The routes of travel by which the pioneers gained access to the haunts of our beavers and to our fertile acres were mainly three: First, via the Great Lakes to Green Bay, thence up the Fox river to. Lake Winnebago, thence across to the Portage, and down the Wisconsin river ; ${ }^{2}$ second, via the Ohio river, thence up the Mississippi and Missouri rivers; third, overland by wagon. The degree of use of these routes before the advent of the railroad can only be surmised. Prior to 1845 certainly the river routes were the highways chiefly used by the westward bound emigrants. ${ }^{3}$ From 1845 overland travel by wagon became increasingly common until the railroad became a practicable mode of travel, round about $1860 .^{*}$

\footnotetext{
1 Salter's Iowa, p. 31.

2 Featherstonehaugh's Geological Reconnaissance, pp. 121-123; $;$ and History of Clayton County (Interstate Pub. Co.), pp. 250-254.

3 L. H. Lengworthy's Dubuque, Its History, Mines, Indian Legends, p. 5 ; N. H. Parker's Iowa As It Is in 1855, pp. 53.61, and J. M. D. Burrows' Fifty Years in Iowa (1838-1888) pp. 33-36, 62-63.

4 Annals of Iowa (3d ser.), vol. 1I, pp. 264.
} 
With such commercial and industrial attractions and such routes of travel thereto we should naturally presume that Iowa's pioneer population in the main hailed from the land of the pines and from south of Mason and Dixon's line. Indeed, when we consider the nature of the industries of the people to the northeast and southeast prior to 1840 , and the economic effects upon redundant population such a conclusion seems to be enjoined.

The first people to penetrate and frequent Iowa in any numbers were the French and Canadian hunters, traders and voyageurs. No large or durable French settlements, however, were found when the immigrants began to come into the State after 1830. From this fact it is perhaps commonly assumed that people of French extraction or of Canadian lineage formed no considerable proportion of the State's early. population. This conclusion, however, is hardly warranted. But as our special concern here is the major factor in the pioneer population, I shall pass over this interesting element and turn immediately to the population that came into Iowa via the Mississippi river and overland by wagon. From what section did the major or predominant number come?

We may determine this in various ways; first, by noting the nativity of the men chiefly in control in the State's prenatal period; second, by ascertaining the nativity of the first residents in numerous sections; third, by the nativity of the men in power in the territorial and State governments in the pioneer days prior to 1850 ; fourth, by comparison of the returns of the national census of 1850 ; fifth, by a study of the industrial, political, religious and social habits and institutions of the pioneers; sixth, by a study of contemporary opinion; seventh, by a similar study of the pioneer immigration into and emigration from the states of the Ohio valley, namely, Pennsylvania, the Virginias, Kentucky and Tennessee, Ohio, Indiana and Illinois, Wisconsin and Missouri. Space limits permit but brief consideration of some of these modes of approach to the subject.

VoL. VII.-29 
The nativity of the officers in charge of the governmental agencies in a region often, if not usually, indicates the nativity of the pioneer population-at least it points to the origin of the major political and social influences that prevail when the political habits and institutions of the people are being established. In the first settlements of the upper Ohio valley the hardy pioneers usually pushed ahead of the army and the assessor and justice of the peace; but in the Louisiana Purchase the military authority always; and often the civil jurisdiction of the national government were "extended" over its vast unsettled regions previous to or coincident with the influx of settlers. The reports and correspondence of such officers would naturally have a pronounced'influence upon relatives, old friends and neighbors "back in the states" that would induce emigration to the. region where "splendid opportunities" awaited those who would but.take them.

When France released her authority over the Louisiana Purchase in 1804, the region embracing Iowa was for a short time attached to the territory of Indiana, over which William Henry Harrison, a son of old Virginia, was governor. At St. Louis, in 1804, he negotiated the treaty by which the United States gained the right of access to most of the lands of the Sacs and Foxes. It was a Marylander, Gen. James Wilkinson, stationed then at St. Louis, who ordered Lieut. Zebulon M. Pike forth on his exploring trip up the Mississippi. Col. George Davenport, a one time partner in the American Fur Company, and influential in the history of Scott county and Davenport, served under Wilkinson, being with him on the Sabine during the trouble with Aaron Burr.' Among the officers stationed at Ft. Madison in the winter of 1808-9 was a Kentuckian, Lieut. Nathaniel Pryor, a member of the Lewis and Clark Expedition."

\footnotetext{
1 ANNals of Iowa (1st ser.), vol. I, p. 99. After his discharge from the army Col. Davenport was employed in the service of Col. William Morrison of Kentucky, a government contractor.

2 See Annals of Iowa (3d ser.), vol. III, pp. 98-99. Tuttle in his History of Iowa (p. 60) credits Zachary Taylor with constructing Ft. Madison but it seems without warrant. ANNAL8, p. 99.
} 
The first governor having intimate relations with the re: gion embracing Iowa was Capt. Meriwether Lewis, a son of Virginia, the leader of the Lewis and Clark Expedition. The Brigadier General and Indian Agent for the territory was his distinguished companion, Capt. William Clark, another son of Virginia. Upon the organization of Missouri territory (that included Iowa) in 1812, Gen. Clark was made governor, holding the office until 1821, when Missouri entered the Union. Governor Clark's voice, however, continued potent in the region as Indian Agent until his death in 1838; one noteworthy instance being the treaty of 1824 ; whereby the Half Breed tract was established. It was at the instance of Gen. Clark that Antoine LeClaire, afterward so prominent in the history of Scott county, was taken into the American service and given an English schooling to enable him to serve as an interpreter. " Among the first "white" women in Clayton county, it is claimed, was a former slave or house servant of Gen. Clark. She was a mulatto. ${ }^{2}$

During the period from 1821 to 1834 , when Iowa was merely a part of the unorganized territory of the United States, its affairs were looked after by officers of the army and Indian Agents, whose work consisted mainly of pro. tecting the Indians against aggressions of the whites. Among them were many southerners who later acquired great fame in national affairs. The first officer sent to look after the Galena miners was Col. Willoughby Morgan, a Virginian. ${ }^{3}$ Col. Zachary Taylor was another Virgin: ian with whom the miners in Dubuque came into direct collision on July 4, 1830. Col. Taylor ordered them to disperse and on their refusal sent troops from Ft. Crawford to arrest them. Years after he declared to Mr. Langworthy that "those miners at Dubuque were worse to manage than the Seminoles' or even the Mexicans." Associated some-

I ANN ALS OF Iowa (1st ser.), vol. I, pp. 145-146:

2 History of Clayton County, p. 251.

3 Wis. His. Coll., vol. VI, p. 272.

+ Langworthy's Dubuque, pp. 18-21, 21 . 
what intimately with Taylor, especially during the Black Hawk war, was a Kentuckian of note, Lieut. Jefferson Davis. He is declared to have acted with and for Taylor when the Mission School for the Winnebago Indians was established in Allamakee county in 1854. ${ }^{1}$ Davis was also assigned to the adjutantship of the First U. S. Dragoons, of which Henry Dodge was colonel. - In that regiment Davis, we are told by the late Gen. James C. Parrott of Keokuk, himself a Marylander, was a "great crony of my [Parrott's] Capt. Browne." 2 The captain referred to was Jesse B. Browne, afterwards one of the first merchants of Keokuk and the speaker of Iowa's first territorial house of representatives that convened in Burlington in December, 1838. With another Iowan, G. W. Jones, later of Dubuque, Jefferson Davis: formed in those early days a fast friendship that endured until death severed the ties-a friendship that had a momen. tous influence upon the political views and conduct of one, if not both of Iowa's first senators, a friendship that eventually caused the imprisonment of Gen. Jones on the charge of treasonable conduct during the civil war. With that same regiment was Lieut. Albert M. Lea, a North Carolinian, whose report on explorations throughout Iowa determined the site of the second Ft. Des Moines, and the publication of: his little book of "Notes," in Philadelphia in 1836. Another southerner of note in the same regiment was Capt. Nathan. Boone, the youngest son of the great Daniel Boone, of Kentucky. He aided Lieut. Lea greatly in furnishing data for the latter's map of Iowa. ${ }^{3}$

Another distinguished southerner intimately associated with the preterritorial days of Iowa was Robert E. Lee. With respect to Lee Mr. Langworthy suggests that it was. probably largely due to his report to congress in 1838 that. Iowa received her name." There are some who claim that.

1 History of Allamakee County, F, 368.

2 ANm a Ls (3d ser.), vol. III, p. 367.

3 Iowa Hist. Rec., vol. VI, P. 550.

4 Langworthy's Dubuque, p. 41. 
Lee county was named in honor of the efficient and genial officer who studied the region of the Rapids so thoroughly." One of the classmates of Davis and Lee at West Point.was afterwards a notable figure in Iowa's history, Charles Mason, for many years Judge of the Supreme Court and subsequently the author of the Iowa Code of 1851. In the service with these men, especially in connection with the Black Hawk war, were Generals E. P. Gaines, a Virginian and Henry Atkinson, a North Carolinian, after whom Ft. Atkinson, located on Turkey river in Winneshiek county, was named. At this fort was stationed Capt. J. J. Abercrombie, a Tennesseean, and Lieut. Alfred Pleasanton, a Washingtonian, both of whom rose to high rank in the Union army, and Lieutenants Simon B. Buckner, Henry Heth, Abraham Buford and Alex. W. Reynolds, all of whom became general officers in the Confederate army. ${ }^{2}$ Another conspicuous figure in the negotiations with the Sacs and Foxes following the Black Hawk war was also a Virginian, Gen. Winfield Scott.

Next to Gen. William Clark, of Missouri, the most noteworthy Indian Agent of the national government immediately charged with the supervision of the interests of the Indians in Iowa and Wisconsin, was "a grand old Virginian,", Gen. Joseph M. Street. It was he who strove so vigorously to initiate the policy of mission schools among the Indians. His services for the nation's wards won for him honorable distinction in the Indian annals of the middle west. He lies buried in the graveyard at Agency City, Iowa, near-by the grave of the chief Wapello, of the Sacs and Foxes. Gen. Street's son-in-law, Capt. George Wilson, was in the same company with Jefferson Davis at Ft. Crawford: Both were in the company that expelled the Dubuque miners. ${ }^{4}$ Capt. Wilson later became the first adjutant of the militia of the

1 Annals (1st ser.), vol. I, p. 894.

2 Annals (3d ser.), vol. IV, p. 452.

3 Judge George G. Wright's characterization, ANNals (3d ser.), vol. II, p. 387.

4 Annals (3d ser.). vol. IV, p. 565. 


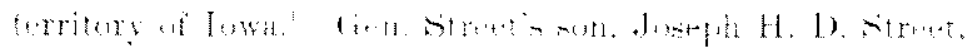

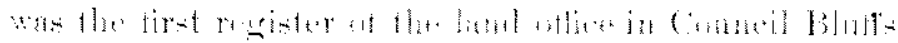

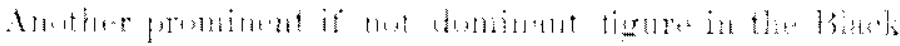

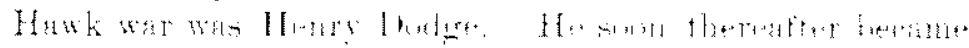

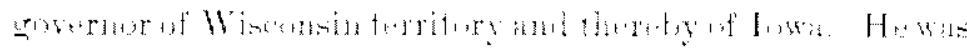

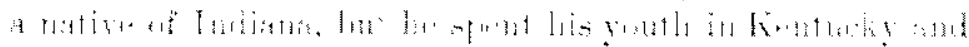

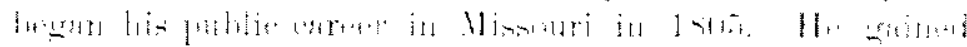

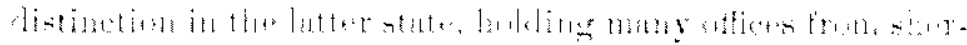

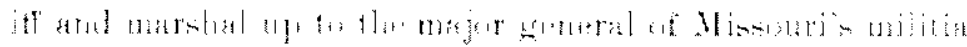

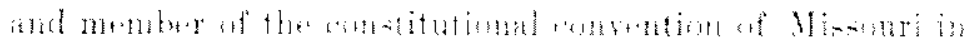

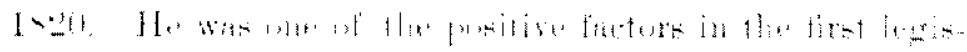

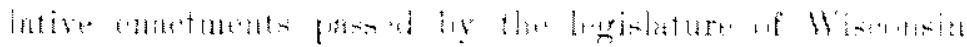

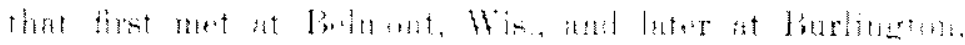
Iowit,

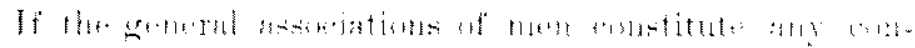

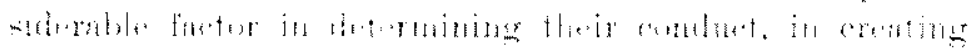

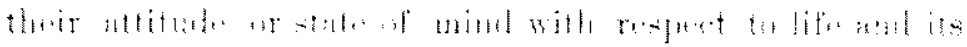

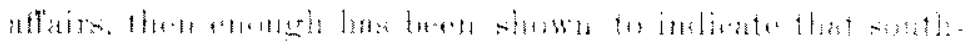

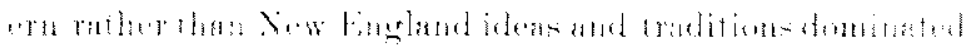

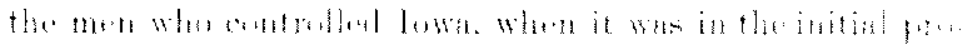

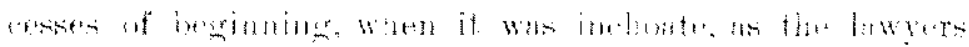

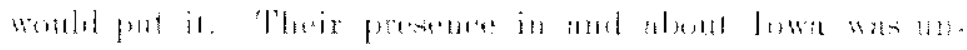

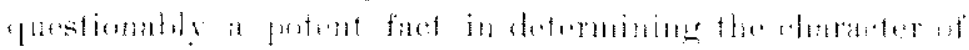

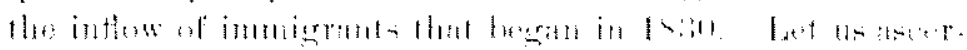

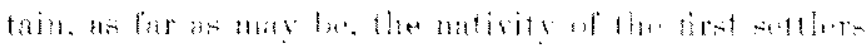

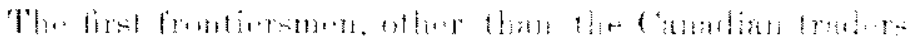

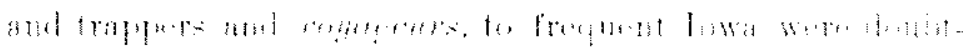

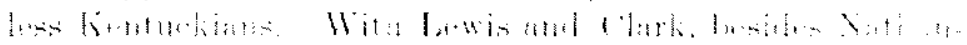

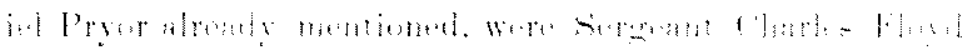

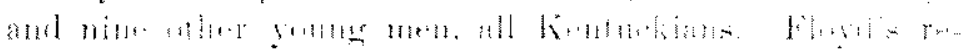

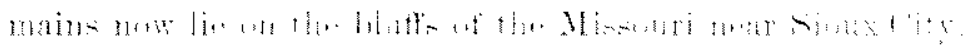

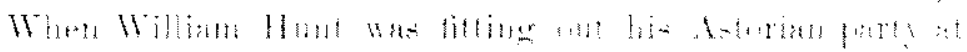

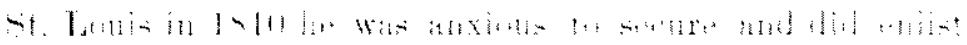

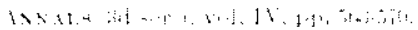

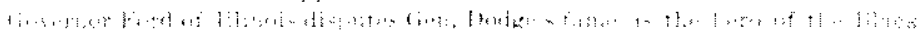

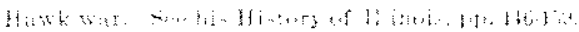




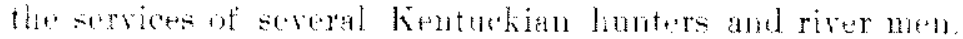

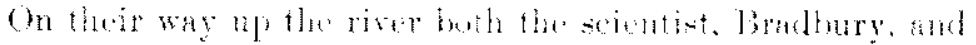

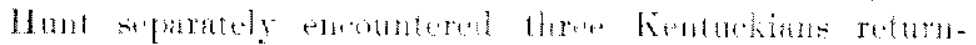

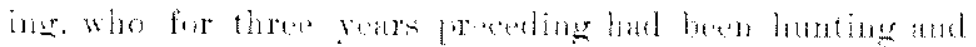

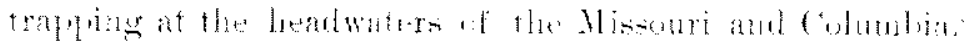
That many of theste "ment of the western waters" hat

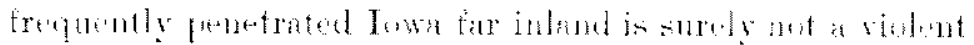
fixtsumptim.

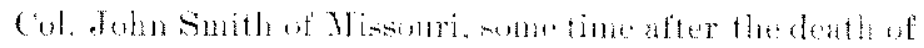

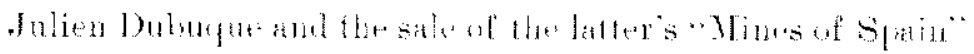

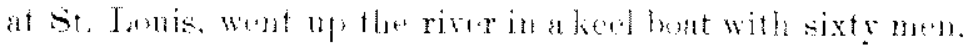

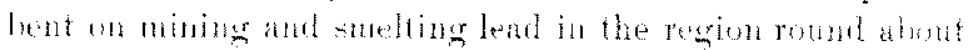

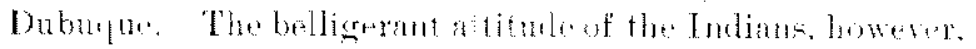
etfectually interfered with his plans." The inhahinuts of

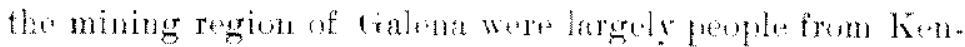

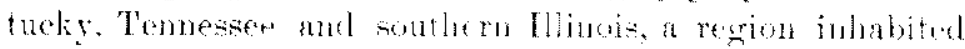

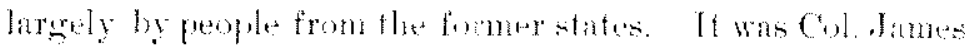

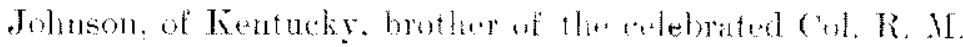

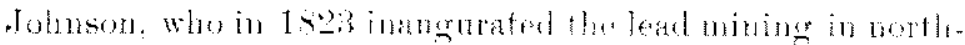

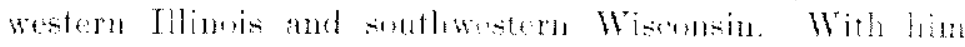

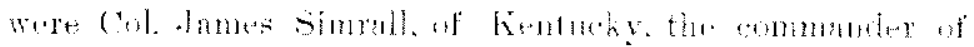

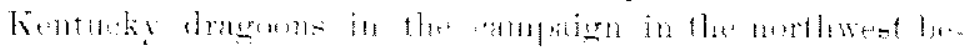

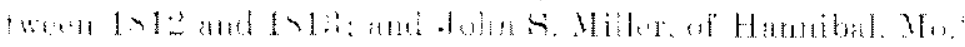

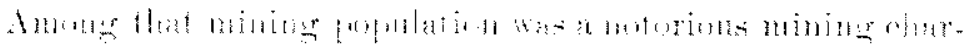

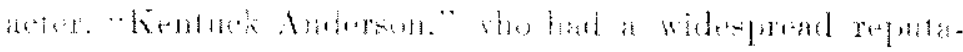

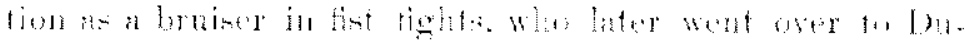

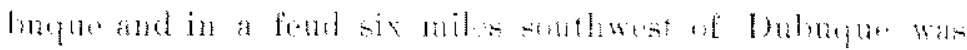
killul in $183 \%$;

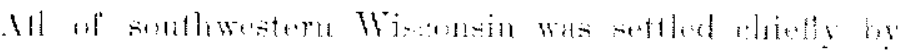

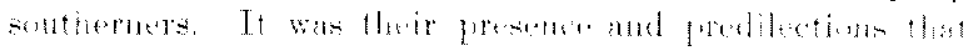

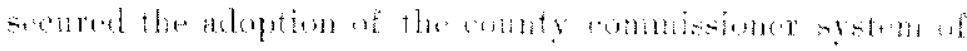

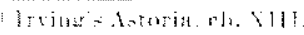

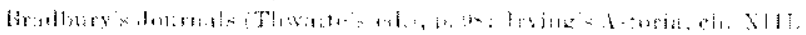

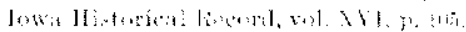

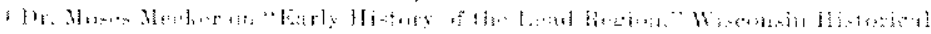

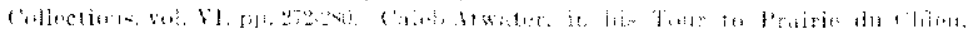

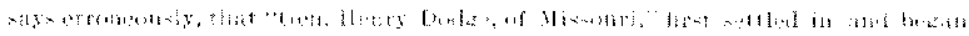

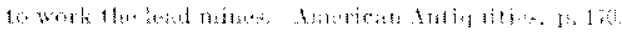

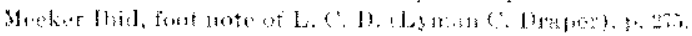


local government in Wisconsin, and maintained it until the state was admitted into the Union in 1848, despite the wishes and protests of the New Englanders and New Yorkers who had gained control in Michigan and who were rapidly coming into Wisconsin. ${ }^{1}$ Col. Arthur Cunynghame traveling across Illinois in 1850 encountered numerons caravans or. wagon trains of the. Kentuckians and Tennesseeans from the Galena mines returning for the winter to their homes. south of the Ohio. ${ }^{2}$ We shall see later that the Dodges and Governors Clark and Hempstead, were among those interested in lead mining around Galena. Iowa, no doubt received prior to 1850 , no inconsiderable number of the southern people from southern Wisconsin and northern Illinois. It is clear that the people who first began to look with covetons eyes across the Mississippi to the attractive lands in - Towa in the main hailed from the south.

We find southern men, or men of southern extraction, or of southern affiliation no less conspicuous and prominent in the gcvernment of the territory and State prior to 1850 and even well up to the outbreak of the civil war. Governor Robert Lucas, the first chief executive of the territory, was a native of Virginia, a descendant of that sturdy Scotch-Irish stock that so early pushed westward through the gaps of the Alleghanies into the valleys converging on the Ohio. His successor, John Chambers, although born in New Jersey in 1789, spent his life mainly in Kentucky from 1792 to 1844. In his old age he returned to Kentucky where he died. Governor James Clark was born in Westmoreland county, Penn. In 1836 he went to Missouri, thence to Belmont, and finally to Burlington. He married a daughter of Governor Henry Dodge, and thereby probably resulted his appoint. ment. The first governor of the new. State. was Ansel Briggs, a Vermonter, a whig in Ohio, who became a democrat when he settled in Jackson county, Iowa, in 1836.

\footnotetext{
1 Wis. Hist. Goll., vol. VI, pp. 502, 506, 507. Spencer's. Local Government in Wisconsiv.

2 Cunynghame's A Glimpse at the Great Republic, p. 52.
} 
His successor, Stephen Hempstead, although born in Connecticut, spent his youth in St. Louis, gained business experience in the lead mining region of Galena and settled in Dubuque in 1836. Governors James W. Grimes and Ralph P. Lowe were northern men by birth and affiliation. Governor Samuel J. Kirkwood was a Marylander, moulded as was Governor Lucas by a subsequent residence in Ohio.

In the relation of the territory and State to the national government, southerners and men of southern predilections were likewise dominant in most of the important positions. The first federal judge was John James Dyer, a native of Pendleton county, Virginia, now West Virginia. But for his refusal to consider the democratic nomination he probably would have been the first governor of the State of Iowa. ${ }^{1}$ The United States marshal was Dr. Gideon S. Bailey of Van Buren, a native of Kentucky. Judge Dyer's successor in 1855 was another Virginian, James M. Love. Iowa's first territorial delegate to congress was W. W. Chapman, who was born and educated in Virginia under the tutelage of the noted lawyer St. George Tucker." His successor in 1841 was Augustus Cæsar Dodge, a son of Governor Henry Dodge, born during the latter's residence in St. Genevieve, Mo., and he was Iowa's national representative until the State was admitted into the Union in 1846. When the first legislature broke the -senatorial deadlock of 1846 , the first senators elected were A. C. Dodge and George W. Jones. The latter was born at Vincennes, Indiana, spent his youth in Missouri, and was educated at Transylvania University, Kentucky. One could without doing violence to language claim one and perhaps both of Missouri's distinguished senators as Iowa's guardians and representatives in congress. Thomas H. Benton had, as is well known, a direct family interest in Iowa through his nephew. who early attained distinction in Dubuque and later in State affairs in Iowa, and

\footnotetext{
1 Iowa Historical Record, vol. XIII, p. 3.

2 Ibid, II, p. 244.
} 
Senator Lewis F. Linn was a half-brother of Governor Henry Dodge. So industrious was Senator Linn on behalf of the interests of this State that he was known as the "Iowa Senator."

Iowa's first representative in the lower house of congress was Shepherd Leffler, of Burlington; William Thompson of Mt. Pleasant, was our second; both sons of the Keystone state. Daniel F. Miller, our third representative, was born in Maryland, and our fourth, Lincoln Clark of Dubuque, was born in Massachusetts, but he had been a resident of Alabama from 1830 to 1848 . Of the six other representatives in congress prior to 1860 one, James Thorington of Davenport was a North Carolinian, and Timothy Davis of Dubuque was a New Jerseyan who lived in Kentucky from 1817 to 1847.

Striking evidence of the domination of men of southern affiliations and antecedents in Iowa's political affairs prior to 1850 , and even beyond, is afforded in the membership rolls of the early legislatures and constitutional conventions. The delegation from this side of the Mississippi in the Wisconsin legislatures that met first at Belmont and later at Burlington, numbered 18 out of the 39 members. Of Iowa's quota there was only one representative of New England, and one from New York, whereas there were four from Pennsylvania (three being from Washington county). The south had 8 representatives: one each from Virginia and Georgia, and three each from Kentucky and Tennessee. There was one each from Ohio and Illinois. In the first legislature of the Iowa territory in 1838 , there were 20 southerners, $5 \mathrm{New}$ Englanders, 8 from the middle states, and 5 from Ohio and Illinois. Virginia, North Carolina, Kentucky and Tennessee were the southern states represented. Disregarding the southern stock among the people of Pennsylvania, Ohio and Illinois, sons of the south constituted more than half of the membership. The records of nativity are not complete for subsequent sessions and the states of origin 
cannot be given except for the State senate in 1851, and the fifth general assembly that met in 1854 . In the senate of the third general assembly (1851) southerners continued the most numerous, 7 as against 2 from New England. In 1854, however, we note an increase in the relative proportions of the representatives from the middle and northwest states. Nevertheless there were in the senate 10 southerners and only 4 New Englanders, and in the lower house 16 from the south and but 9 from northeast of the Narrows.

In the constitutional conventions that convened in 1844 , 1846 and 1857 we find men hailing from south of Mason and Dixon's line greatly outnumbering the New Englanders. In the first convention there were 11 Virginians, 6 North Car. olinians, 8 Kentuckians, and 1 Tennesseeen, 26 in all; while New England was represented by 10 ; the middle states by 23, of whom 13 came from Pennsylvania; Ohio had 8, and Indiana and Illinois each one. In the second the num. bers were 15 from the south, 8 from New England, 4 from the middle states, and 5 from the northwest states. In the convention of 1857 the south had 10, New England 6, the middle states 11 and the northwestern states 9 representatives.

NATIVITY OF SOME OF IOWA'S LEGISLATIVE REPRESENTATION. ${ }^{1}$

\begin{tabular}{|c|c|c|c|c|c|c|c|c|c|c|}
\hline \multirow[b]{2}{*}{ Born in } & \multicolumn{4}{|c|}{ Territorial Legislatures } & \multicolumn{3}{|c|}{ Sta te Assemblies } & \multicolumn{3}{|c|}{$\begin{array}{l}\text { Constitutional } \\
\text { Conventions }\end{array}$} \\
\hline & 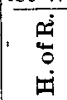 & $\begin{array}{l}\overline{0} \\
0 \\
8\end{array}$ & 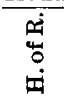 & $\begin{array}{l}\overline{0} \\
80 \\
0\end{array}$ & 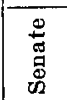 & 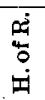 & 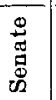 & 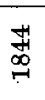 & $\underset{\substack{1 \\
\infty}}{+1}$ & 点 \\
\hline New Engle & 1 & & 2 & 3 & 2 & 9 & 4 & 10 & 8 & 6 \\
\hline Middle S & 3 & 2 & 5 & 3 & 4 & 26 & 9 & 23 & 4 & 11 \\
\hline Southern States & 6 & 2 & 15 & 5 & 7 & 16 & 10 & 26 & 15 & 10 \\
\hline NorthwestStates & 1 & 1 & 4 & 1 & 5 & 15 & 6 & 10 & 5 & 9 \\
\hline Europe... & 1 & 1 & & $\cdots$ & $\cdots$ & 3 & 2 & 3 & ... & $\cdots$ \\
\hline Total & 12 & 6 & 26 & 12 & 18 & 69 & 31 & 72 & 32 & 36 \\
\hline
\end{tabular}

1 Figures in table, reading from left to right, are based upon Salter's Iowa, pp. 209-210; Fulton's Sketches of the Northwest, p. 154 ; a MS. in the Aldrich Collection; Senate Journal 1854 Appendix, pp. 246-248, 520-521; Shambaugh's Constitutional Conventions, 1844 and 1846, Appendices A and B; and Debates of Constitutional Convention (1857) vol. I, p. 4. 
Among the pioneers opinions were now and then expressed concerning the nativity of the population. As we might anticipate the subject was not one that, amidst the press of efforts to subdue forest, prairie and stream, would seriously engage attention or elicit seasoned opinion. Personal associations, especially political and religious affiliations, usually narrowed vision and interfered with impartial judgment. A few recorded opinions are found that are of interest although they are somewhat divergent; some were expressed early in the history of the State, some in memoirs and recollections published in recent years.

Writing to Peter Cooper in 1868 Governor Samuel Merrill, a native of Maine who came to Iowa in 1856 , declared that the State was "settled mainly from Ohio, Indiana and Pennsylvania, with a large admixture from New England." Judge Francis Springer, also a son of Maine, who represented.Louisa and Washington counties in the territorial council in 1840-41, and in 1857 became president of the third constitutional convention, stated in his "Recollections," published in 1897, that "the first settlers of Iowa, it has been said, were from southern Ohio, Indiana and Illinois." " Professor L. F. Parker, one of Iowa's pioneer teachers and historians, writing in 1893 said that "the earliest settlers came largely from southern Ohio, Indiana, Illinois and the most northerly of the southern states; Pennsylvania soon furnished a large contingent. . . . About 1854 large additions were made to the population from New England and from its earlier overflows into New York and northern Ohio."'3 Mr. George Duffield of Keosauqua, a pioneer of 1837, has recently told us that when his father, James Duffield, started west in 1837, there were thousands of settlers "on the move" towards Iowa leaving Pennsylvania and Ohio. "They [the Duffields] were joined on their way down the Ohio by movers from the Carolinas, Kentucky and other.

1 ANNALs (1st ser.), vol. VII, p. 102.

2 Annals (3d ser.), vol. II, p. 575.

3 L. F. Parker's Higher Education in Iowa, p. 11. 
states, and all were afloat in keel boats, 'broads' and steamboats." 1 The observation of the late Theodore Parvin respecting the settlement of sons of the Old Dominion in southeastern Iowa has already been quoted. ${ }^{2}$ According to Hawkins Taylor "Yankees were a scarce article" in Lee county in the first years of the territory. ${ }^{3}$ During the winter of 1841 the late Mr. James Hilton of Monroe county made "a pedestrian tour of the counties of Lee, Des Moines, Henry, Jefferson and Van Buren" and he found that "by far the greater part of the settlers in that part of Iowa were from Virginia, Kentucky and Indiana. . ."4

These three opinions are especially noteworthy. They were expressed by men whose experience with and knowledge of the pioneers were both extensive and official. Each opinion was expressed in connection with or relative to a critical event in the life of the territory or the State. The nativity of the people was consciously considered in the first and third and evidently in mind in the second: hence their significance.

When the first proposals for the organization of the territory of Iowa were being urged upon congress, the lynxeyed, far-seeing guardian of slavery, Calhoun, was stoutly opposed. George W. Jones, the delegate of Wisconsin who urged our case "told him that the inhabitants were mainly from Missouri, Kentucky and Illinois; that the institutions. of the south had nothing to fear from them. Mr. Calhoun replied that this state of things would not last long; that men from New England and other states where abolition sentiments prevailed, would come in and drive him from power and place." ${ }^{5}$ The error of both Jones and Calhoun was their lack of appreciation of the abolition or anti-slavery sentiment among the southerners who came north.

\footnotetext{
1 ANNals (3d ser.), vol. VI, p. 425 ; or Memories of Frontier Iowa, p. 29.

2 Ante, pp. 368-9.

3 Annals (1st ser.), vol. VIII, p. 339.

4 ANN Als (3d ser.), rol. VI, p. 464.

5 Quoted from Salter's Iowa, pp. 229-230.
} 
Writing to Salmon P. Chase upon conditions in Iowa in 1856, Governor Grimes declared: "the southern half of our State is strongly pro-slavery, but I think we will be able to carry a majority with us for free principles. . . The north third of our State will be to Iowa politically what the Western Reserve is to the state of Ohio." 1 The implications plainly are: first, people of southern sympathies, if not of southern lineage numerically prevailed in Iowa up to 1856 ; second, the same was true of southern Ohio; and third, the opponents of slavery, if they were to win in their fight against the arrogant advance of the leaders of the southern system had to depend upon the division of the southern residents in Iowa. The latter fact has not been fully appreciated in Iowa. No more has a similar state of facts in southern and western Pennsylvania, in Ohio, Indiana and Illinois.

In 1859 , excluding slavery, the question that vexed Iowans locally more than any other mutter was the continuance of the county judge system that was instituted in 1851 . The gross disregard of economy in financial administration, and often flagrant misuse of their autocratic powers in many districts outraged the dearest traditions of the New Eng. landers and New Yorkers who came into Iowa in such numbers between 1850 'and 1860 . Mr. Julius ${ }^{\circ}$ H. Powers was elected to the senate in $\mathbf{1 8 5 9}$ from a district in north central Iowa comprising nine counties. He was chairman of the senate committee on county and township organization. In describing the contest in the legislature over the attempt to revolutionize the system of local government, Mr. Powers explains the animus of the struggle, and so far as I can discover he is the only observer or writer who has perceived the profound social and political consequences of the different streams of pioneer immigration into Iowa in the ante bellum period:

Two tides had flowed into Iowa in populating the State, one from the

\footnotetext{
1 Salter's Grimes, p. 54.
} 
east, bringing the New England element and habits, with its memory of town meetings and individual rights, and one from the south bringing with it the southern element with its thoughts and polity.

In the early settlement of the State the southerner had largely predominated, and the State's early organization was fashioned and moulded by that influence, and the old baronial system. had been perpetuated through the slave power where necessity required a centralizing. To abolish this one man power and disburse it among the many was looked upon by the southern element as dangerous in the extreme, and considerable bitterness was engendered when a change was demanded.

Party lines were thrown down, and former influences and surronndings controlled the vote. 1

All these things may be so; and still the numerical preponderance of southern stock in Iowa prior to the civil war is by no means demonstrated. The predominance of southerners among the men charged with the supervision of this region in the preterritorial days may have been a mere chance occurrence. The preference of the national government for men of southern blood or views in the territorial appointments was due, some may contend, to political conditions affecting the entire nation. Again the large number of southerners in our early legislative and constitutional assemblies, while very suggestive, is not in and of itself proof of the numerical preponderance of southern stock. And as to opinions they usually are based on promiscuous and vagrant impressions. The facts may be far different.

We have three census enumerations, the federal counts of 1850 and 1860 , and the state census of 1856 , that enable us to determine, with precision, the nativity of Iowa's pioneers at the close of the period hereunder consideration. A comparative study of their returns enable us clearly to discern the predominant elements in the previous decades.

According to the federal census of 1850 the number of native born New Englanders in Iowa was only 5,535; of which 813 were natives of Maine, 580 of New Hampshire, 1,645 of Vermont, 1,251 of Massachusetts, 256 of Rhode Island, and 1,090 of Connecticut. The pioneers. hailing from the middle states aggregated 24;516; Pennsylvania was

1 Powers' Historical Reminiscences of Chickasaw County, pp. 240-241. 
credited with 14,714 , and New York with 8,134 . The total number born in the southern states amounted to 30,954 . Virginia gave us 7,801, Maryland 1,888, North Carolina 2,589, Tennessee 4,274, Kentucky 8,994; and Missouri 3,897. From the states of the old Northwest territory we received 59,098 ; Ohio sending us 30,713 , Indiana 19,925 , and Illinois 7,247. The native born Iowans numbered 50,380.

There are some striking exhibits in the foregoing. In the first place the inhabitants of Iowa who claimed New England as their place of birth did not number four in the hun. dred of the population of 1850 . Second, the number hailing from the southern states was nearly six times the number coming from east of the Hudson. Third, there were more native born Virginians than there were native born New Englanders altogether. Fourth, the number of Kentuckians likewise outnumbered the total number coming from New England.

The enumerations of 1856 and 1860 show some increases, both absolutely and relatively, in the numbers hailing from New England and the middle states. Nevertheless the people of the south continued to outnumber the natives of New England three and two to one, as may be seen from the following summary. Even in 1860 the Virginians in Iowa alone exceeded the total number coming from Connect. icut, Massachusetts and Vermont:

NATIVITY OF NATIVE BORN PIONEERS OF IOWA.

\begin{tabular}{|c|c|c|c|c|c|c|}
\hline & \multirow{2}{*}{1850} & \multirow{2}{*}{$1856^{1}$} & \multirow{2}{*}{1860} & \multicolumn{3}{|c|}{ Percentage } \\
\hline & & & & 1850 & 1856 & 1860 \\
\hline New England......... & 5,535 & 18,389 & $\overline{25,040}$ & 3.2 & 4.3 & 4.4 \\
\hline Middle States......... & 24,516 & 85,196 & 103,173 & 14.3 & 20.0 & 18.1 \\
\hline Southern States.... & 30,954 & 54,942 & 54,006 & 18.1 & 12.9 & 9.4 \\
\hline Northwest States $\therefore$ & 59,098 & 172,303 & 193,005 & 34.5 & 40.6 & 33.9 \\
\hline Iowa ............ & 50,380 & 93,302 & 191,148 & 29.6 & 21.9 & 33.7 \\
\hline Other States...... & 138 & 122 & 2,460 & .8 & .3 & .5 \\
\hline Total natives .. & 170,621 & 424,254 & 568,832 & & & ; . \\
\hline
\end{tabular}

The significance of these figures cannot be appreciated, however, until we realize that the peoples coming to Iowa

1 Some of the items included in the totals here given are so blurred in the original tables that the numbers below may be subject to slight corrections. 
from Delaware, from southern and western Pennsylvania and from Ohio, Indiana, Illinois and southern Wisconsin were likewise predominantly southern in their ancestry, affiliations and traditions. This fact, I believe, is no less demonstrable than the preponderance of southerners in Iowa in ante bellum days.

The New England tradition must be adversely considered, and presumptuous though it may seem, Justice Miller's judgment must be reversed; the decision must be Iowa was settled first by sons of the Old Dominion interspersed with the vigor of New England. Upon such a holding much that is inexplicable in Iowa's history becomes easily understandable. We can readily appreciate why Senator Dodge could so confidently proclaim in the senate in 1854 that he and his colleague, General Jones, with thersenator from Pennsylvania were the only senators from the north who had voted against the Wilmot Proviso and for the fugitive slave. law; and-why Governor Grimes found the south half of Iowa so strongly pro-slavery.

This predominance of southern stock among Iowa's pioneers, the prevalence of southern traditions among the dominant political forces of the State prior to the civil war had ineradicable effects upon the life and institutions of Iowans. Throughout the entire history of the State one may discern a sharp cleavage among the people of Iowa that in general typifies the traditional conflict between the Cavalier and the Puritan. It is manifest not only in the political life of the State but in the social life of the people, in industry and commerce, in church and religion, in education and modes of recreation-sundry phases of which the writer hopes some time to set forth. 
Copyright of Annals of Iowa is the property of State of Iowa, by \& through the State Historical Society of Iowa and its content may not be copied or emailed to multiple sites or posted to a listserv without the copyright holder's express written permission. However, users may print, download, or email articles for individual use. 